\title{
Upaya Tiongkok dalam Mengatasi Ketimpangan Pembangunan Antardaerah pada Masa Kepemimpinan Jiang Zemin dan Hu Jintao
}

\author{
Adi Wibawa, Puguh Toko Arisanto \\ Program Studi Hubungan Internasional, Universitas Teknologi Yogyakarta - Indonesia \\ Email: adi.wibawa@staff.uty.ac.id \\ Diserahkan: 6 Agustus 2019 | Diterima: 25 Desember 2019
}

\begin{abstract}
The Chinese economic revolution launched since 1978 by Deng Xiaoping put national economic growth as a priority but ruled out the aspect of equity which was one of the main characteristics of the socialist state. The reVolution resulted a spectacular national economic growth as well as inequality between regions in China. Therefore, the Chinese Government, since the leadership of Jiang Zemin and continued by $\mathrm{Hu}$ Jintao, has been trying to improve the condition. This article will explain the strategies and policies of equitable development between regions in China during the reign of Jiang and Hu. By using descriptive qualitative methods, the data used are secondary data obtained from official publications of the Chinese government and supported by scientific articles that can be accessed through the internet. The results obtained indicate the seriousness of the Chinese Government under Jiang and Hu in revising national development priorities. The target of economic growth is lowered and no longer became a priority of development programs. On the other hand, underdeveloped regional development programs such as infrastructure and industrial development are accelerated to catch up with the developed regions.
\end{abstract}

Keywords: Chinese, Development, Policy, Inequality, Jiang Zemin, Hu Jintao.

\begin{abstract}
Abstrak
Revolusi ekonomi Tiongkok yang digulirkan sejak tahun 1978 oleh Deng Xiaoping menjadikan pertumbuhan ekonomi nasional sebagai prioritas namun mengesampingkan aspek pemerataan yang menjadi salah satu ciri negara sosialis. Sehingga hasil yang diperoleh dari revolusi ekonomi tersebut adalah pertumbuhan ekonomi nasional yang spektakuler sekaligus angka ketimpangan antardaerah di Tiongkok yang juga tak kalah tinggi. Oleh sebab itu, Pemerintah Tiongkok, sejak masa kepemimpinan Jiang Zemin dan dilanjutkan oleh $\mathrm{Hu}$ Jintao, telah berusaha untuk memperbaiki kondisi tersebut. Tulisan ini akan menjelaskan strategi dan kebijakan-kebijakan pemerataan pembangunan antardaerah di Tiongkok pada masa pemerintahan Jiang dan Hu. Dengan menggunakan metode kualitatif deskriptif, data yang digunakan berupa data sekunder yang diperoleh dari publikasi-publikasi resmi pemerintah Tiongkok serta didukung dengan artikel-artikel ilmiah yang dapat diakses melalui media internet. Hasil yang didapatkan menunjukkan keseriusan Pemerintah Tiongkok di bawah Jiang dan Hu dalam merevisi prioritas pembangunan nasional. Target pertumbuhan ekonomi diturunkan dan tidak lagi menjadi prioritas program pembangunan. Sebaliknya, program-program pembangunan daerah tertinggal seperti pembangunan infrastruktur dan industri dipercepat untuk mengejar ketertinggalan dari daerah-daerah yang lebih maju.
\end{abstract}

Kata Kunci: Revolusi, Pembangunan, Kebijakan, Ketimpangan, Jiang Zemin, Hu Jintao.

\section{PENDAHULUAN}

Pada awal tahun 2018, konstelasi politik global digegerkan dengan isu trade war atau perang dagang antara dua raksasa ekonomi dunia saat ini, yakni 
antara Tiongkok dan Amerika Serikat (AS). Berdasarkan data yang dikeluarkan Bank Dunia, pada tahun 2017, AS menempati urutan pertama negara dengan perekonomian terbesar dengan $24,32 \%$ dari total perekonomian dunia sementara Tiongkok menempati urutan kedua dengan proporsi 14,84\% (Smith, 2018). Digambarkan dalam Thucydides Trap bahwa Tiongkok sebagai the rising power diprediksi akan mengambil alih pimpinan dunia dari the rulling power, AS. Dengan kata lain era ini menjadi era kebangkitan Tiongkok setelah tenggelam dalam beberapa abad silam. Kebangkitan Tiongkok tersebut pada gilirannya mengancam dominasi AS dalam tatanan internasional (Allison, 2018).

Jauh sebelum perang dagang berlangsung, Tiongkok sudah mencuri perhatian dunia saat berhasil menggeser Jepang pada tahun 2010 yang pada saat itu menempati urutan kedua negara dengan perekonomian terbesar di dunia. Selain itu, Tiongkok juga berhasil menjadi negara eksportir terbesar di dunia dengan nilai ekspor yang mencapai US\$2,06 triliun pada tahun 2016 dan selalu mencatatkan pertumbuhan ekonomi di kisaran angka 10\% per tahun sejak tahun 2003 (OEC, t.t). Dalam ukuran komparasi nilai ekspor terhadap GDP (Gross Domestic Product), Tiongkok diakui sebagai negara megatrader terbesar dunia dimana $40 \%$ GDP Tiongkok berasal dari aktifitas ekspor (Winanti, 2015).

Gambaran keberhasilan ekonomi Tiongkok tersebut membuat kebanyakan pengamat memandangnya sebagai contoh keberhasilan pembangunan negara yang bisa menjadi trendsetter dan patut diadopsi oleh negara-negara lain khususnya negara-negara berkembang. Namun, pada kenyataannya pembangunan Tiongkok tidak sesempurna yang kebanyakan dilihat para pengamat. Perumbuhan ekonomi yang melejit justru meninggalkan berbagai permasalahan sosial seperti korupsi, kesenjangan sosial, dan jumlah populasi yang membengkak.

Permasalahan tersebut tidak dapat dilepaskan dari kebijakan pemerintah Tiongkok pada awal reformasi ekonomi pada tahun 1978. Visi pembangunan ekonomi yang dijalankan pemerintah Tiongkok di bawah Deng Xiaoping saat itu meyakini bahwa "bukan masalah kucing itu putih atau hitam selama ia masih bisa menangkap tikus," (Cable, 2017, p. 3) artinya pemerintah Tiongkok kala itu tidak perlu peduli dengan bagaimana komunisme Tiongkok diterapkan selama itu bisa memberikan manfaat sebesar-besarnya bagi negara mereka. Pada praktiknya, berbagai aspek pembagunan cenderung dikorbankan demi 
mencapai pertumbuhan ekonomi, tidak terkecuali aspek pemerataan pembangunan (equitable development).

Diperkenalkannya strategi "Tiga Daerah Ekonomi” pada tahun 1985, pemerintah Tiongkok berupaya untuk memprioritaskan daerah timur dalam menggenjot pertumbuhan ekonomi nasional dengan memberikan berbagai keistimewaan (privileges). Hasilnya, daerah timur tumbuh pesat sedangkan pembangunan daerah tengah dan barat relatif terabaikan.

Gambar 1. Peta pembagian 3 daerah Tiongkok

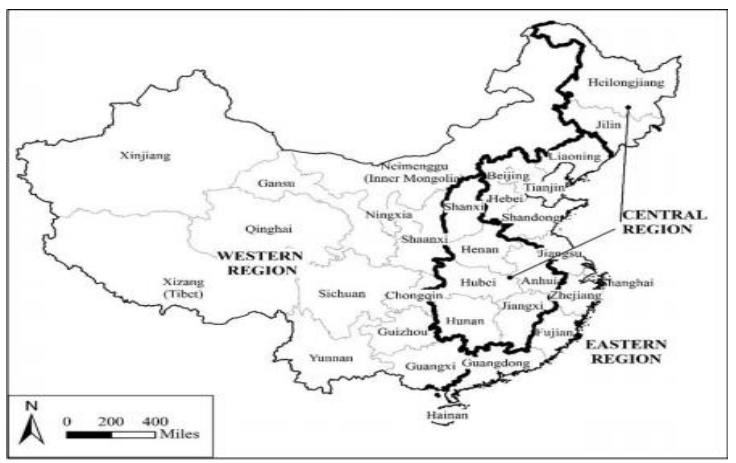

Sumber: Liao \& Wei, 2016.

Masalah ketimpangan pembangunan antardaerah di Tiongkok baru mendapat perhatian khusus dari pemerintah sejak kepemimpinan Jiang Zemin (19932003) dan dilanjutkan oleh suksesornya, Hu Jintao (2003-2013). Tulisan ini berusaha memaparkan rekam jejak ketimpangan pembangunan antardaerah di Tiongkok dan bagaimana permasalahan itu coba diatasi pemerintah sampai akhir masa kepemimpinan $\mathrm{Hu}$ Jintao.

\section{KERANGKA KONSEPTUAL}

\section{Perdebatan Teori-Teori Pembangunan}

Istilah "Pembangunan" menjadi perdebatan dalam beberapa dekade terakhir. Redefinisi secara kontinyu terjadi karena adanya kegagalankegagalan pembangunan di masa lalu serta munculnya sudut pandang baru dalam melihat pembangunan. Pada era tahun 1960-an, muncul Dependency Theory (teori ketergantungan) yang lahir dari kritik terhadap pembangunan di negara-negara Dunia Ketiga, terutama di negara-negara Amerika Latin yang sangat bergantung pada negara-negara maju. Beranjak ke era tahun 1970-an, pembangunan lebih dimaknai sebagai upaya pemenuhan basic needs (kebutuhan dasar manusia) dibanding sebagai upaya mencapai pertumbuhan ekonomi semata (Winarno, 2013). Pergeseran pandangan ini muncul karena pertumbuhan ekonomi yang pesat di negara-negara berkembang pada saat itu gagal terdistribusi secara merata dan justru hanya memunculkan serta memperlebar kesenjangan.

Berdasarkan pandangan pertumbuhan ekonomi tradisional, tingkat keberhasilan pembanguan suatu negara kerap diukur berdasarkan 
besarnya Gross National Product (GNP) dan Gross Domestic Product (GDP). Di luar kedua tolak ukur tersebut, keberhasilan pembangunan secara ekonomi juga dapat dilihat dari besarnya GNP maupun GDP per kapita. Besaran GNP maupun GDP per kapita dapat menggambarkan kemakmuran masyarakat di suatu wilayah dan sejauh mana pembanguan telah dicapai. Setelah tahun 1970-an, pertumbuhan ekonomi tidak lagi hanya diukur berdasarkan indikatorindikator tersebut. Pertumbuhan ekonomi yang dicapai belum dapat dikatakan berhasil sebagai suatu proses pembangunan jika tingkat kemiskinan, ketimpangan pendapatan, dan pengangguran di negara tersebut masih tinggi. Sejak saat itu, selain perhitungan GDP danGNP, besaran angka kemiskinan, ketimpangan pendapatan, dan pengangguran dimasukkan ke dalam tolak ukur keberhasilan pembangunan secara ekonomi (Todaro, 1999).

Berbeda dari dimensi ekonomi, keberhasilan pembangunan dalam dimensi sosial cenderung lebih sulit untuk diukur. Pada tahun 1970-an, Perserikatan Bangsa-Bangsa (PBB) melalui United Nations Research Institute on Social Development (UNRISD) merumuskan 16 indikator, terdiri atas 9 indikator sosial dan 7 indikator ekonomi, yang dikenal sebagai Indeks Pembangunan Sosial. Dengan menggunakan indeks ini UNRISD membuktikan bahwa tingkat pertumbuhan GNP per kapita suatu negara tidak selamanya sejalan dengan pencapaian ke-16 indikator pembangunan sosial. Namun, indikator-indikator ini kemudian dikritik karena dua hal. Pertama, mereka terlalu menekankan aspek perubahan struktural sehingga mengesampingkan aspek kesejahteraan manusia yang riil. Kedua, secara implisit, indikatorindikator tersebut menunjukkan bahwa negara-negara berkembang harus mengikuti alur pembangunan negara maju (Todaro, 1999).

Usaha untuk mengukur tingkat pembangunan secara sosial terus dilakukan. Sampai akhirnya pada tahun 1990 PBB melalui United Nations Development Program (UNDP) mengeluarkan terbitan serial berjudul Human Development Reports. Unsur yang terpenting dalam laporan tersebut adalah konstruksi dan penyempurnaan Indeks Pembangunan Manusia (HDI). HDI mencoba memeringkatkan semua negara berdasarkan tiga kriteria hasil pembangunan, yaitu ketahanan hidup (yang diukur berdasarkan tingkat harapan hidup pada saat kelahiran), pengetahuan (berdasarkan tingkat literasi dan angka rata-rata masa sekolah), serta kualitas standar hidup (berdasarkan pendapatan per kapita riil yang disesuaikan dengan 
paritas daya beli atau purchasing power parity) (Todaro, 1999). Meskipun mendapat beberapa kritik, namun sampai saat ini HDI dianggap sebagai tolok ukur pembangunan yang paling komprehensif dan paling banyak digunakan di seluruh dunia.

Dari penjelasan di atas, dapat kita pahami bahwapada awalnya pembangunan dipandang sebagai fenomena ekonomi semata. Tinggi rendahnya kemajuan pembangunan hanya diukur berdasarkan tingkat pertumbuhan GNP dan GDP, baik secara keseluruhan maupun per kapita, serta indikator lain seperti kemajuan infrastruktur dan indeks pembangunan manusia. Namun, pengalaman pada masa itu menunjukkan fakta bahwa banyak negara Dunia Ketiga berhasil mencapai tingkat pertumbuhan ekonomi yang tinggi namun gagal memperbaiki taraf hidup sebagian besar penduduknya. Hal ini menunjukkan bahwa ada yang salah dalam definisi pembangunan selama masa itu (Winarno, 2013).

Pada masa selanjutnya, pembangunan mengalami redefinisi dengan mulai munculnya pandangan bahwa tujuan utama dari usaha-usaha pembangunan ekonomi bukan lagi menciptakan tingkat pertumbuhan GNP yang setinggi-tingginya, melainkan penghapusan atau pengurangan tingkat kemiskinan, penanggulangan ketimpangan, dan penyediaan lapangan kerja dalam konteks perekonomian yang terus berkembang. Hal ini biasa disebut dengan konsep "redistribusi kemakmuran" (Todaro, 1999). Sejak saat itu, pemerataan dan penurunan angka kemiskinan telah dimasukkan ke dalam agenda pembangunan diseluruh dunia.

Dari beberapa fase pendefinisian pembangunan dapat diambil sebuah kesimpulan idealis bahwa pembangunan di masa kini harus dipandang sebagai suatu proses yang multidimensi dengan menempatkan berbagai aspek kehidupan di samping pertumbuhan ekonomi. Dengan mencoba membatasi pembangunan pada aspek pertumbuhan ekonomi dan ketimpangan, karena keterbatasan kemampuan mereka, di berbagai negara kerap muncul perdebatan mengenai aspek mana yang harus didahulukan: mengejar pertumbuhan ekonomi nasional terlebih dahulu, namun mengesampingkan aspek pemerataan, atau mengedepankan pemerataan dengan konsekuensi pertumbuhan ekonomi yang cenderung lebih lambat.Kedua tujuan ini hampir selalu sangat sulit diwujudkan secara bersamaan. Pengutamaan yang satu akan menuntut dikorbankannya yang lain. 


\section{PEMBAHASAN}

\section{Asal Mula Ketimpangan Antardaerah di Tiongkok}

Tiongkok diyakini telah menjalankan proses pembangunan yang tidak seimbang antara daerah timur, tengah, dan barat sejak kekaisaran dinasti Qing masih berkuasa. Beberapa provinsi di daerah pantai seperti Jiangsu, Zhejiang, Fujian dan Guangdong telah membuka pelabuhan-pelabuhannya untuk transaksi perdagangan internasional antara tahun 1500 sampai 1800 . Periode ini disebut oleh beberapa pengamat sebagai fase "globalisasi awal" (Zhao, 2013). Pada saat itu, daerah tengah dan barat Tiongkok semata-mata hanya difungsikan sebagai daerah pendukung bagi perekonomian di daerah timur. Pada masa itu kota-kota di wilayah pesisir timur Tiongkok telah mampu memproduksi $70 \%$ dari total produksi industri nasional, sedangkan wilayah barat belum memiliki industri modern sama sekali. Industrialisasi dan perdagangan yang begitu masif menjadikan beberapa kota dan daerah seperti Shanghai, Tianjin, Jiangsu, Guangdong, dan Manchuria jauh lebih maju dibandingkan daerah lain di seluruh Tiongkok (Liao \& Wei, 2016). Secara garis besar, perjalanan sejarah menuju pembentukan Republik Rakyat Tiongkok memang telah diwarnai dengan kebijakan-kebijakan pembangunan antardaerah yang kurang berimbang. Pada akhirnya ketika RRC diproklamirkan pada tahun 1949, Mao Zedong sebagai pemimpin pertama RRC dihadapkan pada kenyataan bahwa Tiongkok saat itu merupakan negara miskin dengan tingkat ketimpangan pembangunan antardaerah yang begitu besar (Shen, Teng \& Song, 2019).

Sebagai seorang penganut sosialisme sejati, paradigma pembangunan Mao berupaya menjadikan aspek kesetaraan sebagai tujuan utamanya, karena hal tersebut merupakan ciri utama sebuah negara sosialis. Obsesi untuk mencapai kesetaraan ini sangat jelas ditunjukkan dalam dua hal: distribusi pendapatan yang seragam dan tingkat pembangunan yang seimbang di seluruh daerah. Akibatnya, pemerintah pusat Tiongkok mulai mendistribusikan dan menyalurkan investasi dalam jumlah besar, yang sebagian besar berasal dari kawasan pantai di timur, ke wilayah tengah dan barat yang kurang berkembang dengan harapan dapat menciptakan skenario pembangunan yang "seimbang" dan "merata" dengan mempercepat pertumbuhan ekonomi di daerah pedalaman (Li \& Haynes, 2012).

Investasi pemerintah pusat bagi pembangunan daerah tengah dan barat pada era Mao telah berlangsung sejak Rencana Lima Tahun (RLT) yang 
pertama (1953-1957). Dimulai dengan program Great Leap Forward, Pemerintah Tiongkok berambisi meningkatkan produksi besi dan baja secara besar-besaran dengan menggandalkan tenaga para petani yang dimobilisasi. Kebijakan ini berujung pada bencana kemanusiaan terbesar dalam sejarah Negara Tiongkok. Mobilisasi petani ke industri besi dan baja menjadikan produksi bahan pangan jauh menurun. Kelangkaan pangan menyebabkan munculnya banyak wabah penyakit dan kelaparan massal yang berakhir dengan tewasnya puluhan juta penduduk Tiongkok pada saat itu (Jung \& Chen, 2019).

Di saat yang bersamaan dengan Great Leap Forward, Mao juga menggulirkan sebuah proyek ambisius yang dikenal dengan sebutan Third Front. Proyek Third Front lebih didasari oleh kepentingan politik keamanan dibanding semangat pemerataan pembangunan. Third Front sendiri merupakan strategi keamanan yang ditempuh Mao guna melindungi Tiongkok dari ancaman dunia internasional pada saat itu. Mao bermaksud mengalihkan pembangunan industri berat seperti besi, baja, dan persenjataan dari kotakota pesisir (first front) dan daerah sekitarnya (second front) yang rentan akan ancaman ke daerah daratan yang letaknya lebih ke dalam (third front)
(Yasuo, t.t). Untuk merealisasikan kedua program tersebut, Pemerintah Tiongkok melalui RLT Pertama (1953-1957) mengalokasikan 56\% investasi negara ke provinsi pedalaman, $59 \%$ di RLT Kedua (1958-1962) dan puncaknya pada RLT Ketiga (1966-1970) pemerintah mengalokasikan $71 \%$ investasi negara di provinsi pedalaman, dengan sebagian besar di Sichuan, Hubei, Gansu, Shaanxi, Henan, dan Guizhou. Secara keseluruhan, sejak tahun 1965 sampai 1980 pemerintah telah menginvestasikan lebih dari 200 miliar yuan di wilayah tengah dan barat (Global Security, t.t).

Karena sifatnya yang lebih didasari pada kepentingan politik dan keamanan, pada akhirnya stategistrategi yang dijalankan Mao Zedong di atas tidak dapat memberikan banyak kemajuan pada upaya pemerataan di Tiongkok. Sampai akhirnya Mao digantikan oleh Deng Xiaoping di awal dekade 1970. Pembangunan pada masa kepemipinan Deng berbeda jauh dengan pembangunan pada masa Mao. Melalui reformasi ekonomi di tahun 1978, Deng lebih memilih menempatkan pertumbuhan ekonomi sebagai prioritas, sekaligus memaksa ia untuk mengesampingkan masalah pemerataan antardaerah. Kebijakan "open door" menjadi salah satu ciri reformasi ekonomi Deng. Pemerintah Tiongkok perlahan mulai membuka 
diri bagi masuknya investasi asing. Provinsi-provinsi di pesisir pantai seperti Guangdong dan Fujian ditetapkan sebagai Special Economic Zones (SEZ). Letaknya yang dekat dengan Hongkong dan Taiwan diharapkan dapat menjadi jendela Tiongkok untuk masuk ke sistem perdagangan internasional. Penetapan SEZ ini memberikan peluang bagi provinsi-provinsi tersebut untuk menerima Foreign Direct Investment (FDI) yang bermanfaat bagi pembagunan daerahnya. (Azarhoushang, Wu \& Zaroki, 2019).

Strategi Deng di atas telah mengubah wajah perekonomian Tiongkok secara signifikan. Produk Domestik Bruto (PDB) per kapita Tiongkok meningkat sekitar empat kali lipat dari $¥ 657$ menjadi $¥ 2970$ atau sebesar $9,3 \%$ per tahun. Bahkan menurut Bank Dunia, rata-rata pertumbuhan PDB Tiongkok pasca reformasi ekonomi 1978 mencapai sekitar $10 \%$ per tahun, dan menjadi negara dengan pertumbuhan PDB tertinggi di dunia (World Bank, 2019). Namun pencapaian ekonomi yang luar biasa tersebut, justru menjadikanTiongkok menjadi salah satu negara yang paling tinggi angka ketimpangannya, terutama dalam hal pembangunan antardaerah. Pertumbuhan ekonomi Tiongkok sejak reformasi ekonomi pada tahun 1978 memang tidak diiringi dengan pemerataan yang baik. Ketimpangan antardaerah dapat dilihat dari besaran petumbuhan PDB per kapita penduduk di daerah timur, tengah dan barat. Pada periode tahun 1978 sampai tahun 1990, PDB per kapita daerah timur tumbuh paling besar dengan pencapaian $8,29 \%$ per tahun jika dibandingkan dengan daerah tengah yang tumbuh sebesar $7,23 \%$ dan daerah barat sebesar 7,44\%. Ketimpangan ini meningkat di periode berikutnya yaitu antara tahun 1990 samai tahun 2000. Pada periode ini PDB per kapita masyarakat daerah tengah dan barat hanya tumbuh sebesar $9,37 \%$ dan 9,18\% ketika daerah timur dapat tumbuh sampai 12,31\% (Liao \& Wei, 2016).

\section{Reorientasi Kebijakan Pembangunan di Era Jiang Zemin}

Besarnya

ketimpangan pembangunan pada akhir dekade 1980-an, membuat pemerintah Tiongkok saat itu berpikir untuk segera mengubah kebijakan reformasi ekonomi yang telah berjalan sejak 1978. Peralihan kekuasaan dari Deng Xiaoping ke Jiang Zemin, dan ditambah dengan terjadinya krisis finansial Asia tahun 1997, pemerintah Tiongkok mulai mengalihkan fokus pembangunannya ke daerah tengah dan barat untuk memperkuat struktur perekonomian negara yang selama ini rentan terhadap ancaman krisis. Sejak 
saat itu pemerintah mulai merevitalisasi pusat-pusat industri di daerah tengah dan barat yang telah diabaikan sejak reformasi 1978 (Crane, Albrecht, Duffin, \& Albrecht, 2018).

Pada bulan Agustus tahun 1995, sebagai bagian dari persiapan perumusan RLT periode berikutnya, para gubernur dari beberapa provinsi di daerah tengah dan barat melobi pemerintah pusat untuk segera menjalankan langkah nyata dalam mengurangi ketimpangan antardaerah. Keinginan para pemimpin daerah tersebut dikabulkan pemerintah pusat melalui RLT periode 1996-2000, RLT yang pertama di masa Jiang Zemin. Seperti yang dipublikasikan dalam situs berita resmi pemerintah Tiongkok (China.org.cn, t.t.) terdapat enam kebijakan pokok terkait pembangunan daerah dalam RLT, yakni memberikan prioritas pada pengembangan sumber daya dan proyek-proyek infrastruktur dan secara bertahap meningkatkan dukungan keuangan untuk daerah tengah dan barat; (2) mengalihkan industri pengolahan sumber daya dan industri padat karya ke bagian tengah dan barat; (3) merasionalisasi harga produk sumber daya untuk meningkatkan kemampuan pengembangan diri di wilayah tengah dan barat; memperbaiki iklim investasi di daerah tengah dan barat dan mengarahkan lebih banyak investasi asing ke kawasan-kawasan ini; (5) memperkuat kerjasama ekonomi antara daerah timur dengan daerah tengah dan barat; (6) mendorong provinsi-provinsi di daerah timur untuk berinvestasi lebih banyak di daerah tengah dan barat; dan (7) mengarahkan sumber daya manusia yang berbakat ke daerah-daerah ini.

Setelah RLT ini disahkan sebagai patokan awal upaya pemerataan pembangunan, pemerintah Tiongkok di bawah Jiang Zemin merumuskan suatu langkah nyata yang lebih aplikatif. Jiang meluncurkan suatu strategi pembangunan yang secara spesifik menargetkan pengejaran pembangunan di daerah barat yang disebut dengan Western Development Strategy (WDS) pada tahun 1999. Secara umum, WDS merupakan strategi yang diciptakan untuk membuat beragam kebijakan yang telah dan akan dikeluarkan pemerintah menjadi lebih terstruktur. Pada dasarnya strategi ini ditujukan untuk merevitalisasi pusat-pusat industri di daerah barat Tiongkok yang sebelumnya pernah dibangun di era kepemimpinan Mao. Komponenkomponen utama strategi ini di antaranya; pembangunan infrastruktur dan sistem transportasi, jaringan telekomunikasi, dan pembangkit listrik; kebijakan-kebijakan khusus di sektor energi, pertambangan, pertanian dan pariwisata; peningkatan pelayanan pendidikan dan kesehatan; 
serta kebijakan-kebijakan lain untuk menarik investasi asing seperti keringanan pajak dan perizinan (Crane, Albrecht, Duffin, \& Albrecht, 2018).

Untuk merealisasikan strategi WDS, pada bulan Oktober tahun 2000 pemerintah Tiongkok menerbitkan dokumen Notice of the State Council on Implementing Several Policies and Measures for the Western Development Strategy. Dokumen ini berisi panduan pelaksanaan WDS. Setelah itu, pada bulan September tahun 2001 pemerintah kembali mengeluarkan sejumlah kebijakan implementatif yang terangkum dalam Notice of the Opinions of the State Council Western Development Offce on Implementing Policies and Measures for the Western Development Strategy. Melalui kedua dokumen tersebut secara keseluruhan pemerintah telah menerbitkan 70 kebijakan dalam penerapan dan pengukuran keberhasilan WDS (Song, Wu \& Xu., 2019).

\section{Implementasi Kebijakan Pemerataan di Era Hu Jintao}

Baru dua tahun WDS berjalan atau pada tahun 2003, tampuk kepemimpinan Tiongkok beralih dari Jiang Zemin ke Hu Jintao. Hu diangkat menjadi presiden ketika RLT 20012005 yang dirumuskan Jiang Zemin sedang berjalan, sehingga $\mathrm{Hu}$ hanya bertugas untuk meneruskan pelaksanaan kebijakan dan program- program yang telah ditentukan sebelumnya. Setelah RLT tersebut berakhir, pemerintah Tiongkok di bawah $\mathrm{Hu}$ merumuskan RLT berikutnya (2006-2010) yang disebutsebut sebagai RLT yang revolusioner. RLT ini menjadi titik balik yang menggambarkan keseriusan pemerintah Tiongkok di bawah pemerintahan $\mathrm{Hu}$ dalam mengubah prioritas dan strategi pembangunan mereka. RLT ini memberikan peluang bagi masyarakat di daerah-daerah tertinggal untuk dapat turut serta menikmati buah dari pertumbuhan ekonomi Tiongkok yang selama ini belum mereka rasakan.Kesejahteraan yang merata (common prosperity) telah menggeser slogan getting rich first sebagai tujuan pembangunan negara (Naughton, 2005, p. 2).

Untuk menafsirkan slogan pembangunan yang baru ini, pemerintah telah menetapkan berbagai target yang harus dicapai melalui RLT 2006-1010. Di bidang ekonomi, pemerintah menargetkan pertumbuhan PDB per tahun "hanya" sebesar 7,6\% selama tahun 2006 sampai tahun 2010. Angka ini berada jauh di bawah pertumbuhan PDB mereka saat itu (2005) yang sebesar 9,3\%. Selain itu, ditetapkan pula target pertumbuhan penduduk maksimum $0,8 \%$ per tahun, tingkat urbanisasi sebesar $47 \%$, menyediakan lapangan kerja bagi 45 juta tenaga kerja, 
pendapatan meningkat sebesar 4,9\% baik di kota maupun di desa, jangkauan asuransi pensiun perkotaan meningkat dari 170 juta menjadi 223 juta jiwa, jangkauan asuransi kesehatan meningkat dari 23,5\% menjadi $80 \%$ total penduduk perkotaan, dan ratarata pendidikan penduduk meningkat dari 8,5 menjadi 9 tahun. Dalam hal pemerataan, pemerintah berkomitmen untuk tetap melanjutkan upaya pembangunan daerah barat dengan meningkatkan dukungan melalui kebijakan-kebijakan yang mendorong pembangunan yang ditetapkan secara bertahap setelah RLT ini resmi berjalan (Fan, 2006).

Terdapat 18 aspek kebijakan yang akan dikeluarkan pemerintah Tiongkok untuk mempercepat pembangunan di wilayah barat. Kedelapan belas aspek tersebut adalah (1) meningkatkan investasi modal di bidang konstruksi; (2) menentukan prioritas proyek konstruksi; meningkatkan transfer pemerintah pusat; (4) meningkatkan dukungan kredit keuangan; (5) meningkatkan iklim investasi mikro; (6) memberikan keringanan pajak; (7) memberikan kebijakan preferensial agraria; (8) menentukan prioritas investasi eksplorasi sumber daya mineral; (9) mengatur perekonomian daerah; (10) memperbesar peluang bagi investasi asing; (11) memperluas saluran bagi pemanfaatan modal asing; (12) melonggarkan peraturan yang membatasi pemanfaatan modal asing; (13) meningkatkan perdagangan luar negeri; (14) meningkatkan kerjasama dan bantuan regional; meningkatkan daya tarik dan pemanfaatan potensi daerah; (16) menekankan peran ilmudan teknologi dalam pembangunan; meningkatkan input pendidikan; serta (18) memperkuat infrastruktur kebudayaan dan fasilitas kesehatan (Deng \& Bai, 2014, 20). Kebijakankebijakan tersebut dapat dikelompokkan menjadi empat kelompok kebijakan, yakni (1) transfer fiskal dan keringanan pajak; dukungan kredit dan finansial; (3) pembangunan infrastruktur; dan (4) panduan kebijakan dan kerjasama antardaerah.

\section{Transfer Fiskal dan Keringanan Pajak}

Transfer fiskal dari pusat ke daerah merupakan mekanisme yang umum digunakan untuk mendukung desentralisasi seperti yang diterapkan Tiongkok untuk melimpahkan wewenang kepada pemerintah daerah menyediakan berbagai pelayanan publik. Minimnya pendapatan asli daerah di provinsi-provinsi barat menjadikan mereka amat bergantung pada bantuan pemerintah pusat guna menjalankan fungsi-fungsi pemerintahan daerah dalam 
pembangunan. Oleh karena itu, transfer fiskal pemerintah pusat ke pemerintah daerah memainkan peran yang amat penting dalam pelaksanaan program-program pemerataan. Untuk memenuhi kebutuhan tersebut, pemerintah secara bertahap meningkatkan transfer fiskal mereka bagi pembangunan di daerah barat sejak tahun 2000. Antara tahun 2000 dan 2005 setidaknya pemerintah pusat telah mengalokasikan ¥404 milyar untuk pembangunan daerah barat ( $\mathrm{Lu}$ \& Deng, 2013).
Ketika WDS dirumuskan oleh Jiang Zemin pada tahun 1999, transfer fiskal pemerintah pusat yang dialokasikan untuk daerah barat hanya sebesar 29,01\% dari total transfer fiskal pusat secara nasional. Di bawah pemerintahan $\mathrm{Hu}$, setidaknya sampai tahun 2010 rasio ini telah mencapai $39,42 \%$. Jumlah dan persentase kenaikan transfer fiskal dari pemerintah pusat ke daerah barat dari tahun ke tahun dapat dilihat pada Diagram 1 di bawah ini (Lu \& Deng, 2011, p. 4).

Diagram 1 Jumlah dan Presentasi Fiskal Pemerintah Pusat ke Daerah

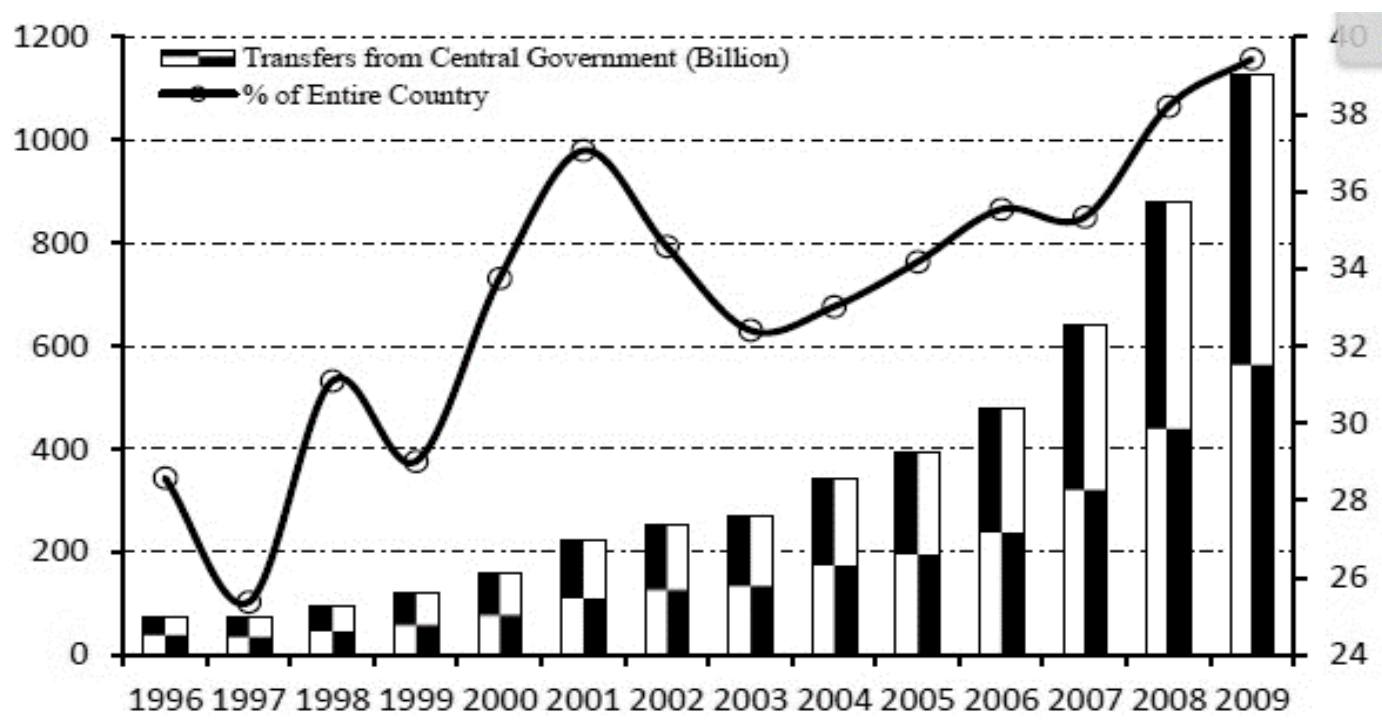

Sumber: Lu \& Deng, 2011, p. 4

Diagram 1 (Lu \& Deng, 2011, 4) di atas menunjukkan bahwa besaran transfer fiskal pemerintah pusat untuk pembangunan di daerah barat meningkat secara konstan dari tahun ke tahun. Bedasarkan persentase nasional, transfer fiskal pemerintah pusat ke daerah barat Tiongkok memang sempat beberapa kali menurun, namun jika dilihat berdasarkan kuantitas, jumlah transfer fiskal dari secara konsisten terus meningkat dari tahun ke tahun. Pada tahun 1999 ketka WDS baru dimulai 
besaran transfer pemerintah ke daerah barat hanya berkisar pada angka $¥ 120$ juta. Angka tersebut terus meningkat selama satu dekade berikutnya hingga tahun 2009 dimana jumlah transfer pemerintah pusat ke daerah barat telah melebihi angka $¥ 1$ milyar. Berdasarkan persentase total transfer fiskal pemerintah pusat, pada tahun 2003 transfer pusat ke daerah barat hanya sebesar 32\%, namun di tahun 2009 persentase tersebut hampir mencapai angka $40 \%$.

Selain transfer fiskal dari pusat ke daerah, kebijakan untuk mengurangi pajak juga menjadi faktor penting yang mempercepa pembangunan di daerah barat. Pengurangan pajak perusahaan menjadi sasaran utama kebijakan ini. Perusahaan-perusahaan, baik domestik maupun asing, yang bergerak di bidang-bidang yang telah ditentukan pemerintah berhak menerima keringanan pajak sebesar 15\%. Bahkan untuk pertama kalinya sepanjang sejarah Tiongkok, sejak tahun 2006 pemerintah menghapuskan secara penuh pajak pertanian (Lu \& Deng, 2013). Perusahaan-perusahaan domestik baru yang bergerak di sektor transportasi, listrik, konservasi air, layanan pos, radio dan televisi di daerah barat dibebaskan dari pajak selama dua tahun pertama. Perusahaan asing juga dapat menikmati kebijakan tersebut jika ia beroperasi selama minimal sepuluh tahun. Pemerintah juga memberikan pembebasan dari tanggung jawab pajak bagi barangbarang impor yang akan digunakan dalam pembangunan proyek-proyek infrastruktur di daerah barat ( $\mathrm{Lu} \mathrm{\&}$ Deng, 2011, p. 4).

\section{Dukungan Kredit dan Finansial}

Peningkatan transfer fiskal dari pusat ke daerah barat harus didukung dengan ketersediaan lembaga keuangan yang memadai untuk membantu pemerintah dalam mengelola dan menyalurkan pendanaan pembangunan. Untuk itu pemerintah dan PBC (People's Bank of China) mengeluarkan regulasi-regulasi bagi bank dan institusi-institusi keuangan agar bersedia menambah jumlah penyediaan kredit bagi pembangunan daerah barat. Hasilnya, sampai tahun 2010 persentase pinjaman yang dikeluarkan DBC (Development Bank of China) untuk pembangunan daerah barat mencapai $22,36 \%$ dari total pinjaman yang dikeluarkan. Angka tersebut meningkat dari tahun 2001 yang hanya sebesar $17,78 \%$. Selain itu, pemerintah juga mendorong bank-bank asing untuk membuka cabang-cabang baru di daerah barat, menggandeng pihak swasta dalam pendirian lembagalembaga keuangan, serta mengembangkan bank dan koperasi di pedesaan (Lu \& Deng, 2011, p. 6). 


\section{Pembangunan Infrastruktur}

Ketimpangan infrastuktur antara daerah maju di pesisir timur dengan daerah tertinggal di tengah dan barat mencakup berbagai sektor infrastruktur seperti industri, energi, transportasi dan sosial. Tidak dapat dipungkiri bahwa ketersediaan infrastruktur memberikan dorongan bagi pertumbuhan ekonomi di daerah. Sebagai contoh, infrastruktur transportasi yang memadai akan memangkas biaya produksi yang kemudian meningkatkan produktivitas daerah.

Sejak digulirkannya WDS, proporsi investasi pemerintah bagi pembangunan infrastruktur di daerah barat terus meningkat dari tahun ke tahun. Tabel 1 di bawah ini menunjukkan persentase alokasi investasi infrastuktur pemerintah Tiongkok bagi daerah barat selama sepuluh tahun pertama WDS (2000 sampai 2010).

Tabel 1. Persentase pembagian investasi pemerintah di bidang infrastruktur berdasarkan daerah (2000-2010)

\begin{tabular}{cccccc}
\hline Tahun & $\begin{array}{c}\text { Daerah } \\
\text { timur (\%) }\end{array}$ & $\begin{array}{c}\text { Daerah } \\
\text { tengah (\%) }\end{array}$ & $\begin{array}{c}\text { Daerah } \\
\text { barat (\%) }\end{array}$ & $\begin{array}{c}\text { Daerah } \\
\text { timurlaut } \mathbf{( \% )}\end{array}$ & $\begin{array}{c}\text { Tidak } \\
\text { terklasifikasi (\%) }\end{array}$ \\
\hline $\mathbf{2 0 0 0}$ & 25,56 & 20,64 & 25,93 & 7,25 & 20,62 \\
\hline $\mathbf{2 0 0 1}$ & 24,46 & 18,39 & 25,61 & 8,82 & 22,71 \\
\hline $\mathbf{2 0 0 2}$ & 17,80 & 17,14 & 34,23 & 6,84 & 23,99 \\
\hline $\mathbf{2 0 0 3}$ & 24,40 & 19,41 & 38,68 & 7,92 & 9,58 \\
\hline $\mathbf{2 0 0 4}$ & 24,70 & 20,03 & 33,61 & 7,61 & 14,05 \\
\hline $\mathbf{2 0 0 5}$ & 24,01 & 19,86 & 32,84 & 9,01 & 14,28 \\
\hline $\mathbf{2 0 0 6}$ & 21,06 & 21,82 & 33,13 & 10,15 & 13,84 \\
\hline $\mathbf{2 0 0 7}$ & 22,17 & 24,39 & 32,12 & 11,16 & 10,16 \\
\hline $\mathbf{2 0 0 8}$ & 23,50 & 24,50 & 33,08 & 10,24 & 8,69 \\
\hline $\mathbf{2 0 0 9}$ & 21,81 & 24,46 & 39,24 & 9,70 & 4,79 \\
\hline $\mathbf{2 0 1 0}$ & 20,64 & 23,77 & 41,15 & 8,70 & 5,74 \\
\hline
\end{tabular}

Sumber: Lu \& Deng, 2011, p. 6.

Sampai dengan tahun 2010, daerah barat telah menjadi tujuan bagi $41,15 \%$ dari total belanja pemerintah di bidang infrastruktur. Hal ini memberikan peluang bagi daerah barat untuk memenuhi kebutuhan pembangunan proyek-proyek infrastruktur yang selama ini belum pernah dilakasanakan. Meningkatnya persentase secara nasional juga diikuti dengan meningkatnya jumlah investasi pemerintah di bidang infrastruktur dari tahun ke tahun. Anggaran tersebut digunakan untuk berbagai proyek pembangunan seperti infrastruktur transportasi, energi, pendidikan dan kesehatan. Beberapa diantara kebijakan pembangunan infrastruktur 
tersebut kemudian dilanjutkan melalui RLT periode 2011-2015. Beberapa proyek utama pembanguanan infrastruktur yang tercantum dalam RLT ini antara lain (Gu, 2012); (1) melanjutkan pembangunan rel kereta antara Lanzhou-Urumqi, LanzhouChongqing dan Guilin-Guangzhou; (2) membangun jalan raya yang akan menghubungkan Beijing dengan Kunming dan Shanghai dengan Chengdu pada akhir periode RLT; (3) membangun rel dan jalan raya untuk menghubungkan Mongolia, Xinjiang dan Qinghai; (4) melakukan renovasi dan pembangunan bandar udara baru untuk meningkatkan hubungan antara daerah barat dengan negara lain; (5) meningkatkan jaringan transportasi minyak dan gas, termasuk proyek pipa minyak mentah China-Kazakhstan, Dushanzi-Urumqi, dan Jiaopiao-RuiliKunming sebagai bagian dari proyek pipa minyak mentah TiongkokMyanmar; (6) meningkatkan pemanfaatan sumberdaya alam daerah untuk mendorong rantai industri; dan (7) meningkatkan upaya pelestarian alam. Area tutupan hutan harus mencakup seperlima dari seluruh tanah di daerah barat dan konsumsi air harus berkurang sebanyak 30\% pada akhir 2015.

\section{Panduan Kebijakan dan Kerjasama Antardaerah}

Dalam upaya merencanakan dan menata pembangunan daerah barat, pemerintah mengeluarkan panduan pembangunan bagi beberapa aspek pendukung (Lu \& Deng, 2011), antara lain; (1) memastikan ketersedian modal bagi pertumbuhan ekonomi daerah barat, pemerintah pusat telah mengeluarkan panduan bagi institusiinstitusi pembiayaan agar meningkatkan jumlah pinjaman modal mereka; (2) untuk modal yang datang dari sektor swasta maupun sumber luar negeri juga diberikan panduan pengalokasian investasi dangan dikeluarkannya Catalogue of Priority Industries for Foreign Investment in the Central-Western Region; (3) selain modal pendanaan, pemerintah juga mengeluarkan panduan untuk mendorong para tenaga kerja terdidik agar mau bekerja di daerah barat dengan Go West College Graduates Volunteer Program. Program ini merekrut para sarjana baru untuk bekerja secara sukarela di daerah barat selama satu sampai dua tahunsebagai tenaga pengajar, kesehatan, dan pengentasan kemiskinan; dan pemerintah juga mengeluarkan kerangka kerjasama antara kota dan provinsi daerah timur dengan provinsi-provinsi di daerah barat dalam program Hand-in-Hand Aid (HHA) dan East-West Interaction (EWI). 
HHA mengarah pada pemberian bantuan infastruktur, pendidikan, teknologi industri, dan investasi modal dari daerah timur ke daerah barat, sementara EWI mendorong peningkatan aliran faktor produksi antardaerah untuk mencapai target produksi nasional.

\section{KESIMPULAN}

Berbagai dinamika yang dilalui dalam pembangunan Tiongkok telah berhasil menempatkan negara tersebut menjadi salah satu negara dengan perekonomian terbesar di dunia. Meskipun demikian, berbagai prestasi perekonomian tersebut tak lantas menjadikan seluruh rakyat Tiongkok dapat menikmati buah pembangunan secara adil dan merata. Ini bisa dilihat dari angka ketimpangan juga tumbuh dengan subur dalam kurun waktu yang bersamaan.

Besarnya angka ketimpangan dan masalah yang ada serta kemampuan ekonomi nasional yang telah memadai kemudian membawa pemerintah Tiongkok di bawah kepemimpinan Jiang Zemin untuk mulai melakukan reorientasi kebijakan pembangunan. Upaya pemerataan pembangunan bagi daerah-daerah tertinggal di bagian barat Tiongkok mulai digulirkan dalam suatu kerangka strategi kebijakan bernama WDS (Western Development Stategy). Jiang mengawalinya dengan mulai memberikan beberapa perlakuan khusus bagi daerah barat melalui berbagai kebijakan yang dikeluarkan pemerintah Tiongkok.

Pemerintah Tiongkok menjadikan RLT yang ke-11 (20062010) sebagai penegasan untuk mengubah arah kebijakan pembangunan. Berlawanan dengan reformasi ekonomi era Deng Xiaoping, kali ini pemerintah Tiongkok rela mengorbankan pertumbuhan ekonomi demi tercapainya common prosperity. Target pertumbuhan ekonomi diturunkan dari tahun-tahun sebelumnya, sebaliknya, pencapaian dalam bidangbidang kesehatan, pendidikan, lingkungan, dan percepatan pembangunan daerah tertinggal terus ditingkatkan. Pemerintah memberikan beberapa stimulus bagi pembangunan daerah barat seperti peningkatan transfer fiskal, kredit, keringanan pajak, pembagunan infrastruktur besar-besaran, serta kerjasama antardaerah.

\section{REFERENSI}

\section{Buku dan Terbitan}

Azarhoushang, Behzad; Wu, Jennifer Pédussel \& Zaroki, Shahryar. (2019) "Chinese regional inequality and sectoral foreign direct investment," Working Paper, No. 119/2019, Hochschule für Wirtschaft und Recht Berlin, Institute for International Political Economy (IPE), Berlin.

Cable, Vince. (2017) "Deng: Architect of The Chinese Superpower," dalam Jie, 
$\mathrm{Yu}$ (ed), From Deng to Xi: Economic Reform, The Silk Road and The Return of The Middle Kingdom, Ideas Publishing, London.Liao, F.H., and Wei, Y.D. (2016) "Sixty Years of Regional Inequality in China: Trends, Scales and Mechanisms," Working Paper Series $N^{\circ}$ 202. Rimisp, Santiago, Chile.

Song, Xiaowu, Wu, Shiguo., \& Xu, Xin. (2019) The Great Change in the Regional Economy of China under the New Normal, Zhejiang University Press, Beijing.

Winarno, Budi. (2013) Etika Pembangunan, CAPS, Yogyakarta.

\section{Artikel Jurnal}

Crane, Bret. (et.al) (2018) “China's Special Economic Zones: An Analysis of Policy to Reduce Regional Disparities," Regional Studies, Regional Science, Vol. 5, No. 1.

Deng, Xiangzheng \& Bai, Xuemei. (2014) "Sustainable Urbanization in Western China," Environment Science and Policy for Sustainable Development, Vol. 56, No. 3.

Fan, C.C. (2006) "China's Eleventh FiveYear Plan (2006-2010) - From Getting Rich First to Common Prosperity,"Eurasian Geography and Economics, Vol. 47, No. 6.

Jung, Hsiung-Shen \& Chen, Jui-Lung., (2019) "Causes, Consequences and Impact of the Great Leap Forward in China," Asian Culture and History, Vol. 11, No. 2.

Li, Huaqun. \& Haynes, Kingsley, (2012) "Foreign direct investment and China's regional inequality in the era of new regional development strategy," Regional Science Policy and Practice, Vol. 4, No. 3.

Lu, Zheng \& Deng, Xiang. (2013) "Regional Policy and Regional Development: A Case Study of China's Western Development Strategy," Annales Universitatis Apulensis Series Oeconomica, Vol. 15, No. 1.
Naughton,B.J. (2005)“'The New Common Economic Program: China's Eleventh Five Year Plan and What It Means," China Leadership Monitor, No. 16.

Shen, Hongyan., Teng, Fei. \& Song, Jinping., (2018) "Evaluation of Spatial Balance of China's Regional Development," Journal Sustainability, Vol. 10, Issue 9.

Zhao, Gang. (2014) “The Qing Opening to the Ocean: Chinese Maritime Policies, 1684-1757," The American Historical Review, Vol. 119, Issue 3.

\section{Artikel Internet}

Gu, J. (2012) China Approves 12 Five Year Plan for Western Region [daring]. Tersedia di: http://www.chinabriefing.com/news/2012/02/27/chinaapproves-12th-fiveyear-plan-forwestern-regions.html (Diakses: 17 Juli 2019).

Lu, Zheng \& Deng, Xiang. (2011) China's Western Development Strategy: Policies, Effects and Prospects, [daring]. Tersedia di: http://mpra.ub.unimuenchen.de/id/eprint/35201 (Diakses: 17 Juli 2019).

The Observatory of Economic Complexity: OEC. (t.t) [daring]. Tersedia di: https://atlas.media.mit.edu/en/profile /country/chn/ (Diakses: 7 Juli 2019).

Report on the Outline of the Ninth Five-Year Plan (1996-2000) for National Economic and Social Development and the Long-range Objectives to the Year 2010 (daring). Tersedia di: http://www.china.org.cn/95e/95english1/2.htm (Diakses: 19 Desember 2019).

Smith, Rob. (2018) The World's Biggest Economies in 2018 [daring]. Tersedia di: https://www.weforum.org/agenda/201 8/04/the-worlds-biggest-economies-in2018/ (Diakses: 5 Juli 2019). 
Third-Front / Third-Line (t.t) Global Security.org (daring). Tersedia di: https://www.globalsecurity.org/militar y/world/china/third-front.htm

(Diakses: 19 Desember 2019).

Yasuo, Onishi. (2001) Chinese Economy in the $21^{\text {st }}$ Century and the Strategy for Developing the Western Region, Institute of Developing Economies, Japan External Trade Organization [daring]. Tersedia di: http://darch.ide.go.jp/idedp/SPT/SPT002200_ 003.pdf (Diakses: 25 Juli 2019).

The World Bank in China. (2019, The World Bank [daring]. Tersedia di: https://www.worldbank.org/en/countr y/china/overview (Diakses: 18 Desember 2019).

\section{Video}

Allison, G.T. Is War Between China and the U.S Inevitable? September 2018, $<$ https://www.ted.com/talks/graham_ allison_is_war_between_china_and_the _us_inevitable/transcript\#t-71389> diakses 8 Juni 2019.

\section{Paper}

Winanti, Poppy S. Penguatan Posisi Runding Indonesia dengan Megatraders dalam Perdagangan Internasional. Paper dipresentasikan dalam Seminar "Forum Kajian Kebijakan Luar Negeri: Penguatan Kinerja Diplomasi Ekonomi Indonesia dalam Menghadapi Perkembangan Rezim Investasi dan Perdagangan Internasional”, UGM, 22 September 2015. 